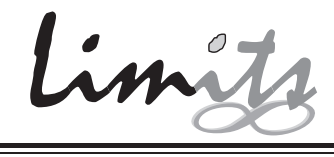

J. of Math. and Its Appl.

ISSN : $1829-605 \mathrm{X}$

Vol. 1, No. 1 (2004), 49-57

\title{
Penerapan Transformasi Wavelet Diskrit Untuk Reduksi Noise Pada Citra Digital
}

\author{
Dwi Ratna \\ Herlina Khukmiati \\ Jurusan Matematika \\ Institut Teknologi Sepuluh Nopember, Surabaya
}

\begin{abstract}
Abstrak
Permasalahan yang dihadapi pada pengolahan citra antara lain terjadinya noise, yang dapat mempengaruhi proses pengolahannya. Oleh karena itu diperlukan suatu proses reduksi noise yang bertujuan untuk mengurangi noise yang terdapat pada citra digital.

Pada makalah ini reduksi noise dilakukan dengan menerapkan transformasi wavelet diskri, yang terdiri dari tiga langkah utama yaitu: dekomposisi citra, proses thresholding dan rekonstruksi citra. Nilai threshold yang digunakan dalam proses thresholding ditentukan dengan tiga metode, yaitu: VisuShrink, BayesShrink dan NormalShrink. Pemilihan filter yang digunakan pada saat dekomposisi dan nilai threshold pada proses thresholding akan mempengaruhi kualitas citra yang dihasilkan.

Hasil implementasi dan uji coba reduksi noise dengan wavelet menunjukkan bahwa filter wavelet Coiflet-5 menghasilkan citra hasil dengan nilai RMSE terkecil. Sedangkan pada metode penentuan nilai threshold, metode yang memberikan hasil paling optimal adalah metode NormalShrink.
\end{abstract}

Kata Kunci:Transformasi wavelet diskrit, Reduksi noise, threshold, VisuShrink, BayesShrink dan NormalShrink

\section{Pendahuluan}

Pengolahan citra digital merupakan salah satu elemen penting dalam berbagai bidang yang melibatkan data berupa citra digital. Permasalahan yang sering dihadapi pada pengolahan citra adalah terjadinya noise ketika pengambilan data. Adanya noise membuat citra menjadi kurang 'sempurna', sehingga dapat mempengaruhi proses pengolahannya. Oleh karena itu diperlukan suatu proses reduksi noise yang bertujuan untuk mengurangi noise yang terdapat dalam citra digital. Proses reduksi noise ini dilakukan melalui pengurangan atau penghapusan data citra yang dianggap sebagai noise.
Pada makalah ini reduksi noise dilakukan dengan menerapkan transformasi wavelet diskrit. Algoritma dari reduksi noise dengan wavelet ini melibatkan tiga langkah pokok yaitu dekomposisi citra digital dengan transformasi wavelet diskrit, kemudian citra hasil transformasi dilewatkan pada suatu fungsi thresholding, dan yang terakhir melakukan rekonstruksi citra dengan invers transformasi wavelet diskrit.

Selain jenis filter yang digunakan, pada reduksi noise dengan wavelet, kualitas citra hasil juga dipengaruhi oleh nilai threshold yang digunakan pada saat thresholding. Metode penentuan threshold ada bermacam-macam, karena itu perlu juga diselidiki metode penen- 
tuan threshold yang memberi hasil yang paling optimal.

\section{Transformasi Wavelet}

Wavelet merupakan salah satu piranti matematika yang mampu melakukan dekomposisi terhadap sebuah fungsi atau sinyal secara hirarkis, membagi fungsi tersebut kedalam komponen frekuensi yang berbeda, dan mempelajari setiap komponen tersebut dengan resolusi tertentu sesuai dengan skalanya. Oleh karena itu, dalam Makalah ini digunakan konsep analisis multiresolusi untuk membangun transformasi wavelet.

Fungsi wavelet dinyatakan dengan notasi $\psi(t)$. Hasil translasi dan dilasi fungsi $\psi(t)$ yaitu:

$$
\psi_{j, k}=2^{-j / 2} \psi\left(2^{-j} \cdot-k\right)
$$

membentuk basis orthonormal dalam $L^{2}(\mathbb{R})$.

\subsection{Analisis Multiresolusi}

Perumusan awal analisis multiresolusi didasarkan kumpulan ruang-ruang vektor $V_{j} \in$ $L^{2}(\mathbb{R})$ yang memenuhi:

$$
\ldots \subset V_{1} \subset V_{0} \subset V_{-1} \subset \ldots \subset L^{2}(\mathbb{R})
$$

atau

$$
V_{j} \subset V_{j-1} \quad \text { untuk semua } j \in \mathbb{Z}
$$

dengan

$$
\lim _{j \rightarrow 0} V_{j}=\{0\}, \quad \operatorname{dan} \overline{\lim _{j \rightarrow \infty} V_{j}}=L^{2}(\mathbb{R})
$$

Jadi, ruang yang memuat sinyal resolusi tinggi juga akan memuat sinyal dengan resolusi rendah.

Selanjutnya ruang vektor $V_{j}$ juga harus memenuhi syarat penskalaan dasar sebagai berikut:

$$
f(t) \in V_{j} \Longleftrightarrow f(2 t) \in V_{j-1}
$$

yang memastikan elemen-elemen disuatu ruang adalah versi terskala dari elemen-elemen di ruang yang mempunyai resolusi lebih tinggi.

Dalam analisis multiresolusi terdapat $\phi \in$ $V_{0}$ sehingga: $\left\{\phi_{0, k}(t)=\phi(t-k): k \in \mathbb{Z}\right\}$ adalah basis orthonormal dalam $V_{0}$. Selanjutnya hasil translasi dan dilasi dari fungsi skala, yaitu $\left\{\phi_{j, k}: k \in \mathbb{Z}\right\}$, dengan:

$$
\phi_{j, k}(t)=2^{-j / 2} \phi\left(2^{-j} t-k\right)
$$

basis orthonormal untuk $V_{j}$ untuk $j \in \mathbb{Z}$.

Berdasarkan (2) dan (5), maka dapat ditunjukkan bahwa jika $\phi$ berada di $V_{0}$ maka $\phi$ juga terdapat di $V_{j-1}$. Sehingga $\phi$ dapat dinyatakan sebagai kombinasi linier dari unsur-unsur basis di $V_{-1}$. Dalam hal ini, $\phi(t)$ dapat dinyatakan sebagai berikut:

$$
\begin{gathered}
\phi=\sum h[n] \phi_{-1, n} \\
\phi(t)=\sum_{n} h[n] \sqrt{2} \phi_{-1, n}, \quad n \in \mathbb{Z}
\end{gathered}
$$

dimana koefisien $h[n]$ merupakan barisan bilangan real yang biasa disebut sebagai koefisien fungsi skala.

\subsection{Transformasi Wavelet Diskrit 1-D}

Langkah selanjutnya dari analisis multiresolusi adalah mendefinisikan ruang wavelet. Untuk setiap $j$ didefinisikan ruang vektor $W_{j}$ yang merupakan komplemen orthogonal dari $V_{j}$ di dalam $V_{j-1}$.

Sub ruang $W_{j}$ dapat didefinisikan dengan persamaan sebagai berikut:

$$
V_{j-1}=W_{j} \oplus V_{j}
$$

dimana $W_{j} \perp W_{i}$ jika $j \neq i$. Jika dimisalkan $j>i$, maka $W_{j} \subset V_{i} \perp W_{i}$. Kemudian untuk $j<J$, maka

$$
V_{j}=V_{J} \oplus \bigoplus_{k=0}^{J-j-1} W_{J-k}
$$

dan jika diasumsikan ruang dengan resolusi tinggi adalah pada skala $j=0$, yaitu ruang dimana sinyal yang akan diproses berada, maka dekomposisi $j$ level dari ruang tersebut akan menghasilkan:

$$
L^{2}=W_{1} \oplus W_{2} \oplus \cdots W_{j-1} \oplus W_{j} \oplus V_{J}
$$

Karena $W_{j}$ ruang komplemen orthogonal dari $V_{j}$ dalam $V_{j-1}$, maka ruang-ruang $W_{j}$ juga mewarisi sifat penskalaan dari $V_{j}$ :

$$
f(t) \in W_{j} \Longleftrightarrow f(2 t) \in W_{j-1}
$$

Persamaan (11) dan (12) membawa akibat bahwa jika $\left\{\psi_{0, k}: k \in \mathbb{Z}\right\}$ adalah basis orthonormal dari $W_{0}$, maka $\left\{\psi_{j, k}: k \in \mathbb{Z}\right\}$ adalah basis orthonormal dari $W_{j}$, untuk setiap $j \in \mathbb{Z}$. 
Selanjutnya dari (9), maka $\psi \subset W_{0} \subset V_{-1}$ dapat dinyatakan sebagai kombinasi linier dari $\phi_{-1, n}$ yang merupakan suatu basis dari $V_{-1}$. Oleh karena itu analog dengan fungsi skala pada persamaan (8), maka dapat ditulis:

$$
\psi(t)=\sum_{n} g[n] \sqrt{2} \phi(2 t-n)
$$

Salah satu karakteristik penting dari basis $\left\{\psi_{j, k}: j, k \in \mathbb{Z}\right\}$ adalah bahwa fungsi anggotanya dalam ruang $W_{j}$ dan fungsi anggota basis $\left\{\phi_{j, n}: n \in \mathbb{Z}\right\}$ dalam ruang $V_{j}$ membentuk basis untuk ruang $V_{j-1}$. Ini berarti bahwa untuk setiap fungsi $f(t) \in L^{2}(\mathbb{R})$ dapat didekomposisi kedalam fungsi wavelet $\psi_{j, k}(t)$ dan fungsi skala $\phi_{j, k}(t)$. Sehingga berdasarkan (11):

$f(t)=\sum_{k} c_{j N}[k] \phi_{j N, k}(t)+\sum_{k} \sum_{j=j 1}^{j N} d_{j}[k] \psi_{j, k}(t)$

dimana $N$ adalah jumlah level dekomposisi.

Koefisien fungsi skala $c_{j}[k]$ disebut juga aproksimasi yang menunjukkan bagian frekuensi rendah dari sinyal. Sedangkan koefisien fungsi wavelet $d_{j}[k]$ disebut dengan detail yang menunjukkan bagian frekuensi tinggi dari sinyal. Koefisien-koefisien $c_{j}[k]$ dan $d_{j}[k]$ dari kombinasi linier pada (14) disebut Transformasi Wavelet Diskrit (TWD).

\section{Proses Dekomposisi}

Dekomposisi merupakan proses memecah suatu sinyal menjadi beberapa komponen dengan resolusi lebih rendah. Dua operasi dasar pada proses dekomposisi adalah filtering dan downsampling. Diagram dekomposisi wavelet diilustrasikan oleh Gambar 1.
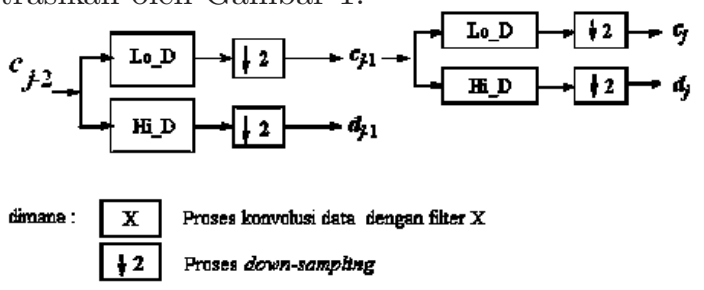

Gambar 1: Proses Dekomposisi Wavelet 1-D Secara matematis proses dekomposisi wavelet dapat dinyatakan oleh persamaan (15) dan (16), yaitu:

$$
\begin{aligned}
& c_{j}[k]=\sum_{m} h[m-2 k] c_{j-1}[m] \\
& d_{j}[k]=\sum_{m} g[m-2 k] c_{j-1}[m]
\end{aligned}
$$

\section{Proses Rekonstruksi}

Proses rekonstruksi, pada dasarnya mempunyai prinsip kerja kebalikan dari prinsip kerja dekomposisi. Hal ini dapat dilihat pada proses filtering dan proses up-sampling, yang merupakan dua operasi dasar pada proses rekonstruksi. Diagram proses rekonstruksi dapat dilihat pada Gambar 2 dibawah ini.

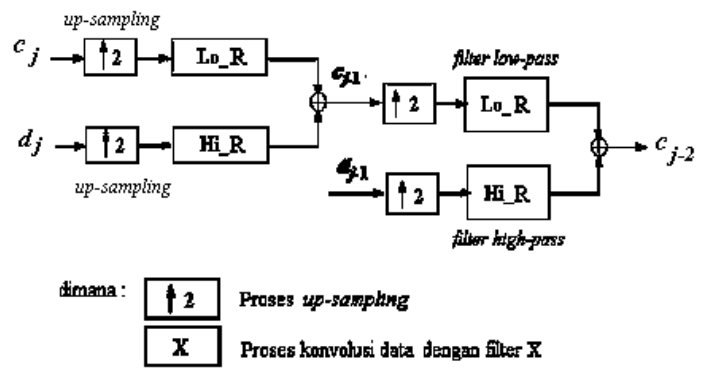

Gambar 2: Proses Rekonstruksi Wavelet 1-D

Secara matematis proses dekomposisi wavelet dapat dinyatakan oleh persamaan (17) sebagai berikut:

$$
\begin{aligned}
c_{j-1}[k]=\sum_{m} & c_{j}[m] h[k-2 m] \\
& +\sum_{m} d_{j}[m] g[k-2 m]
\end{aligned}
$$

\subsection{Transformasi Wavelet Diskrit 2-D}

Model wavelet dapat diperluas untuk ukuran dimensi lain. Sebuah citra yang pada umumnya berdimensi dua dapat diproses lebih lanjut jika model waveletnya terlebih dahulu diturunkan dalam bentuk dua-dimensi.

Sinyal asli sekarang berbentuk $F(x, y) \in$ $L^{2}\left(\mathbb{R}^{2}\right)$. Kemudian karena $L^{2}\left(\mathbb{R}^{2}\right)$ diturunkan dari $L^{2}(\mathbb{R})$, maka pendekatan multiresolusi pada $L^{2}(\mathbb{R})$ masih dipertahankan dalam ruang $L^{2}\left(\mathbb{R}^{2}\right)$.

Analisis Multiresolusi dalam ruang duadimensi juga mempunyai fungsi skala tunggal $\Phi \in \mathcal{V}_{0}$ sedemikian hingga:

$$
\Phi_{0, n_{1}, n_{2}}(x, y)=\phi\left(x-n_{1}\right) \phi\left(y-n_{2}\right)
$$

untuk $n_{1}, n_{2} \in \mathbb{Z}$, membentuk basis orthonormal untuk $\mathcal{V}_{0}$. Kemudian untuk semua $j \in \mathbb{Z}$, hasil translasi dan dilasi dari fungsi skala tunggal tersebut, yaitu:

$$
\begin{aligned}
\Phi_{j ; n_{1}, n_{2}}(x, y) & =\phi_{j, n_{1}}(x) \phi_{j, n_{2}}(y) \\
& =2^{-j} \phi\left(2^{-j} x-n_{1}, 2^{-j} y-n_{2}\right)
\end{aligned}
$$


untuk $n_{1}, n_{2} \in \mathbb{Z}$, membentuk basis orthonormal untuk $\mathcal{V}_{j}$.

Selanjutnya setiap $\mathcal{V}_{j}$ dapat didekomposisi menjadi dua sub ruang $L^{2}\left(\mathbb{R}^{2}\right)$ yang identik, yaitu:

$$
\mathcal{V}_{j}=V_{j} \otimes V_{j}
$$

Analogi pada ruang satu-dimensi, untuk setiap $j$ didefinisikan ruang vektor $\mathcal{W}_{j}$ yang merupakan komplemen orthogonal dari $\mathcal{V}_{j}$ di dalam $\mathcal{V}_{j-1}$. Ruang vektor $\mathcal{V}_{j-1}$ dapat dinyatakan dengan:

$$
\begin{aligned}
\mathcal{V}_{j-1}= & V_{j-1} \otimes V_{j-1} \\
= & \left(V_{j} \oplus W_{j}\right) \otimes\left(V_{j} \oplus W_{j}\right) \\
= & \left(V_{j} \otimes V_{j}\right) \oplus\left(W_{j} \otimes V_{j}\right) \\
& \oplus\left(V_{j} \otimes W_{j}\right) \oplus\left(W_{j} \otimes W_{j}\right)
\end{aligned}
$$

sehingga dapat didefinisikan tiga fungsi wavelet $\Psi(x, y)$ pada $\mathcal{W}_{j}$, yaitu:

$$
\begin{aligned}
& \Psi^{h}(x, y)=\phi(x) \psi(y) \\
& \Psi^{v}(x, y)=\psi(x) \phi(y) \\
& \Psi^{d}(x, y)=\psi(x) \psi(y)
\end{aligned}
$$

dimana $h, v$, dan $d$ berturut-turut menyatakan tiga orientasi horisontal, vertikal, dan diagonal dari fungsi wavelet.

\section{Proses Dekomposisi}

Pada citra 2-D, proses dekomposisi dilakukan atas baris dan kolom dalam array dua dimensi, yang masing-masing bersesuaian dengan arah horizontal dan arah vertikal dalam citra.

Proses dekomposisi koefisien aproksimasi pada level $j$ menghasilkan satu koefisien aproksimasi pada level $j+1$ beserta tiga orientasi koefisien detail (horisontal, vertikal, dan diagonal). Perhatikan iilustrasi pada Gambar 3

\begin{tabular}{|c|c|c|}
\hline $\begin{array}{l}\text { Love12 } \\
c_{2}\end{array}$ & $\begin{array}{l}\text { Loval } 2 \\
d_{2}^{(b)}\end{array}$ & $\begin{array}{c}\text { Dotail horigoxtal } \\
\text { Loveli! } \\
\text { d(b) }\end{array}$ \\
\hline $\begin{array}{l}\text { Level2 } \\
d_{2}^{(\prime)}\end{array}$ & $\begin{array}{l}\text { Level } 2 \\
d_{j}^{(m)}\end{array}$ & subbord $\mathrm{L} H$ \\
\hline \multicolumn{2}{|c|}{$\underset{d(u)}{\operatorname{Lepd} 1}$} & $\begin{array}{c}\text { Dotsil dingaxal } \\
\text { Leved } 1 \\
d_{j}^{(d)}\end{array}$ \\
\hline \multicolumn{2}{|c|}{ subbaxd fII } & subbend FH \\
\hline
\end{tabular}
berikut ini:

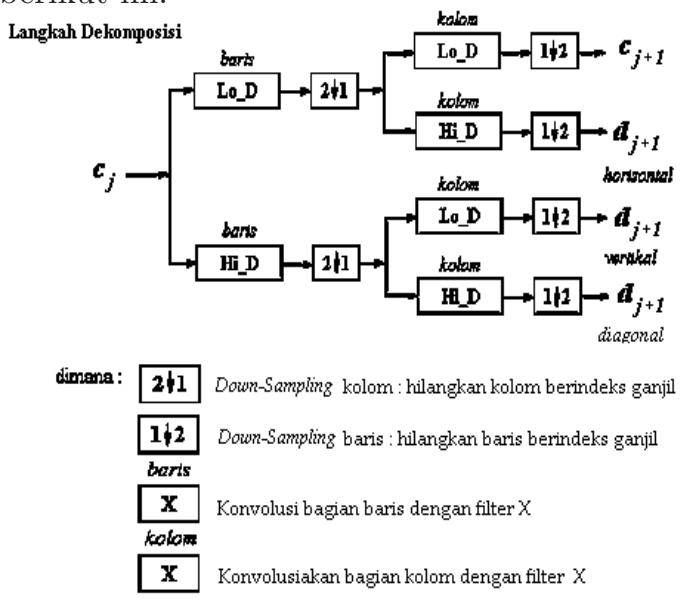

Gambar 3: Diagram Dekomposisi TWD 2-D
Representasi koefisien aproksimasi dan detail yang dihasilkan oleh dekomposisi 2-D level 2 pada citra diilustrasikan oleh Gambar 4 dibawah ini:

Gambar 4: Representasi Koefisien Pada Dekomposisi 2-D level 2

\section{Proses Rekonstruksi}

Rekonstruksi merupakan kebalikan dari proses dekomposisi. Rekonstruksi dilakukan dengan cara mengkombinasikan satu koefisien aproksimasi dan tiga koefisien detail yang dihasilkan pada proses dekomposisi. Pada Makalah ini proses rekonstruksi dilakukan setelah koefisienkoefisien aproksimasi dan detail melewati proses thresholding.

Langkah-langkah proses rekonstruksi 2-D dapat diilustrasikan oleh Gambar 5 sebagai berikut:
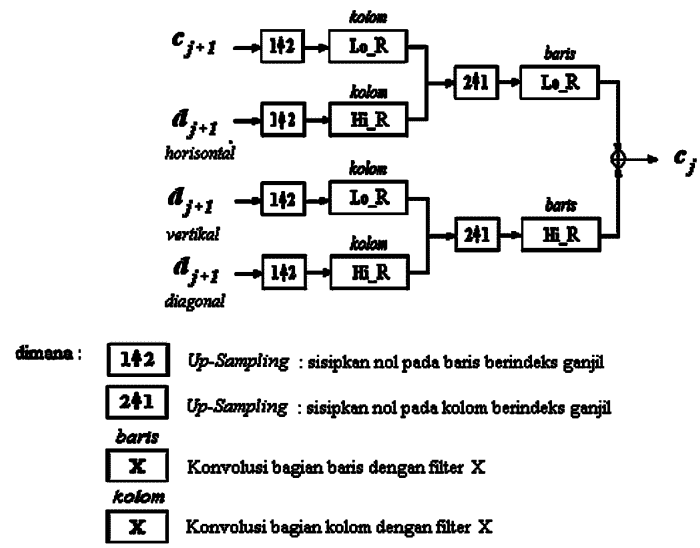

Gambar 5: Diagram Rekonstruksi ITWD 2-D

\subsection{Reduksi Noise Citra}

Reduksi noise citra pada makalah ini bertujuan untuk mengurangi noise yang terkandung pada citra tanpa mengurangi fitur penting dari citra itu sendiri. Proses reduksi noise citra dilakukan setelah mendapatkan hasil transformasi yang berupa nilai koefisien aproksimasi dan tiga ori- 
entasi koefisien detail dari tiap level dekomposisi.

Prinsip kerja reduksi noise ini adalah dengan cara melakukan proses thresholding dengan nilai threshold $t$ pada tiap koefisien detail citra (horizontal, vertikal, dan diagonal). Ide dasar penggunaan proses thresholding bermula dari rumusan David L. Donoho untuk penghalusan sinyal satu-dimensi [5].

Diasumsikan ada sebuah citra masukan $Y_{i j}$ yang terdapat noise didalamnya, dimodelkan dalam bentuk sebagai berikut:

$$
Y_{i j}=X_{i j}+\varepsilon_{i j}
$$

dengan $X_{i j}$ adalah citra hasil yang akan dicari, dan $\varepsilon_{i j}$ adalah white noise-Gaussian yang independen dari $X_{i j}$ dan berdistribusi $\varepsilon_{i j} \sim$ $\mathcal{N}\left(0, \sigma^{2}\right)$.

Tujuan dari proses reduksi noise adalah untuk mendapatkan citra $X_{i j}$ dari citra bernoise $Y_{i j}$. Langkah-langkah reduksi noise berdasarkan formulasi Donoho, adalah sebagai berikut:

i Mendekomposisi citra $Y_{i j}$ menggunakan TWD, sehingga didapatkan koefisien aproksimasi $(c)$ dan tiga orientasi koefisien detail $\left(d^{\lambda}, \lambda=h, v\right.$, dan $\left.d\right)$.

ii Melakukan proses thresholding pada koefisien detail citra, dengan fungsi soft thresholding, yaitu :

$$
\hat{d}^{\lambda}=T_{s}\left(d^{\lambda}, t\right)= \begin{cases}d^{\lambda}-t, & d^{\lambda} \geq t \\ 0, & \left|d^{\lambda}\right|<t \\ d^{\lambda}+t, & d^{\lambda}<-t .\end{cases}
$$

atau hard thresholding

$$
\hat{d}^{\lambda}=T_{s}\left(d^{\lambda}, t\right)= \begin{cases}d^{\lambda}, & \left|d^{\lambda}\right| \geq t \\ 0, & \left|d^{\lambda}\right|<t\end{cases}
$$

Pemilihan fungsi threshold bergantung pada metode yang digunakan dalam mencari nilai threshold $t$. Proses ini menghasilkan nilai koefisien detail terthreshold $\hat{d}^{\lambda}$ (dengan $\lambda$ menyatakan orientasi bidang horisontal, vertikal, atau diagonal).

iii Merekonstruksi kembali citra dari koefisienkoefisiennya dengan menggunakan Invers Transfomasi Wavelet Diskrit (ITWD), sehingga diperoleh citra rekonstruksi $\hat{X}_{i j}$ yang telah tereduksi noisenya.

\section{bf Proses Thresholding}

Proses thresholding merupakan proses dimana reduksi noise itu terjadi. Pada proses ini koefisien-koefisien detail dari citra yang diperoleh melalui proses dekomposisi akan dilewatkan pada fungsi "penyaring" yang disebut dengan fungsi thresholding.

Pada proses thresholding ini koefisien detail citra akan dibandingkan dengan suatu nilai threshold $t$, dan akan mendapat perlakuan sesuai dengan fungsi threshold yang digunakan.

Hasil akhir dari proses reduksi noise, selain dipengaruhi oleh pemilihan filter, juga dipengaruhi oleh nilai threshold $t$, sehingga perlu dipilih metode pencarian nilai threshold yang tepat.

Terdapat dua macam jenis metode threshold, yaitu global threshold dan level adaptive threshold. Pada global threshold, nilai threshold dihitung sekali dan berlaku secara global untuk seluruh level dekomposisi. Sebaliknya pada level adaptive threshold, nilai treshold akan dihitung dari tiap nilai koefisiean detail pada tiap level dekomposisi, sehingga pada tiap level akan diperoleh tiga nilai threshold, untuk koefisien detail vertikal, horisontal dan diagonal [2].

Berikut ini adalah formulasi dari metodemetode pencarian nilai threshold yang digunakan:

\section{a. VisuShrink}

Metode ini dikenalkan oleh Donoho dan Johnstone [6]. VisuShrink termasuk jenis global threshold, sehingga dikenal cepat secara komputasi, karena penghitungan nilai threshold hanya dilakukan sekali. VisuShrink digunakan bersama dengan fungsi hard thresholding. Nilai threshold VisuShrink dihitung dengan menggunakan persamaan sebagai berikut:

$$
t=\sigma \sqrt{2 \log M}
$$

dimana $\sigma$ adalah standar deviasi dari noise dan $M$ adalah ukuran citra.

Standart deviasi dari noise $(\sigma)$ yang ada pada citra masukan dapat diestimasi dari koefisien detail citra dengan menggunakan:

$$
\begin{array}{r}
\hat{\sigma}=\frac{\operatorname{Median}\left(\left|Y_{i j}\right|\right)}{0,6745}, \\
Y_{i j} \in \text { subband } d_{1}^{\text {(diagonal })}
\end{array}
$$




\section{b. BayesShrink}

Metode BayesShrink dikenalkan oleh Martin Vetterli dan Grace Chang. BayesShrink termasuk dalam level adaptive threshold, dimana nilai threshold dihitung dari tiap nilai koefisien detail pada tiap level dekomposisi [2]. Nilai threshold dihitung menggunakan persamaan sebagai berikut:

$$
t_{B}=\frac{\sigma^{2}}{\sigma_{X}}
$$

dengan $\sigma^{2}$ variansi dari noise, yang dapat diestimasi dengan menggunakan Persamaan (26). Sedangkan $\sigma_{X}$ adalah standard deviasi dari citra $X_{i j}$ pada Persamaan (21), kemudian karena $X_{i j}$ dan $\varepsilon_{i j}$ saling independent, maka $\sigma_{X}$ dapat diestimasi dengan:

$$
\hat{\sigma}_{X}=\sqrt{\max \left(\left(\sigma_{Y}^{2}-\sigma^{2}\right), 0\right)}
$$

dimana $\sigma_{Y}^{2}$ adalah variansi citra $Y$, dan $\sigma_{Y}^{2}$ dihitung dari tiap koefisien detail dengan menggunakan persamaan berikut:

$$
\sigma_{Y}^{2}=\frac{1}{n^{2}} \sum_{i, j=1}^{n} Y_{i j}^{2} .
$$

Metode BayesShrink ini digunakan dengan menerapkan fungsi soft thresholding.

\section{c. NormalShrink}

NormalShrink seperti halnya BayesShrink, juga termasuk level adaptive threshold. Nilai threshold NormalShrink digunakan bersama dengan fungsi soft thresholding, dan nilai thresholdnya dicari menggunakan persamaan dibawah ini [7], yaitu:

$$
t_{N}=\frac{\beta \sigma^{2}}{\sigma_{Y}}
$$

dengan $\sigma^{2}$ adalah variansi dari noise, $\sigma_{Y}$ adalah standar deviasi dari koefisien detail dan $\beta$ adalah parameter skala. Variabel $\sigma^{2}$ dapat diestimasi menggunakan Persamaan (26), dan variabel dapat dihitung dengan menggunakan persamaan:

$$
\beta=\sqrt{\log \left(\frac{L_{k}}{J}\right)}
$$

$L_{k}$ adalah panjang koefisien pada level ke- $k$, dan $J$ adalah jumlah level dekomposisi.

\section{Perancangan dan Imple- mentasi Perangkat Lunak}

\subsection{Perancangan Perangkat Lunak}

\section{Deskripsi Sistem Perangkat Lunak}

Sistem perangkat lunak ini dibuat dengan menerapkan transformasi wavelet diskrit untuk reduksi noise pada citra digital. Sistem perangkat lunak pertama kali akan mentransformasi citra input dari user yang berupa citra dengan resolusi $2^{-j}$ menggunakan transformasi wavelet diskrit menjadi koefisien-koefisien dengan resolusi $2^{-(j+1)}$. Kemudian koefisienkoefisien itu akan direduksi noisenya melalui proses thresholding, dimana nilai thresholdnya dicari dengan beberapa meteode tertentu.

Setelah itu sistem akan merekonstruksi kembali koefisien-koefisien yang telah tereduksi noisenya. Melalui invers transformasi wavelet diskrit koefisien-koefisien tersebut akan dikembalikan ke bentuk citra yang tereduksi noisenya, dan ditampilkan kepada user melalui layar monitor.

\section{Format File Citra Digital}

Format file citra yang digunakan pada perancangan perangkat lunak ini berupa array 2-D yang merupakan matrik dengan ukuran $N \times N$. Citra tersebut merupakan citra grayscale, yaitu citra yang mempunyai 256 level nilai dengan jangkauan antara nol sampai 255. Nilai tersebut menyatakan nilai keabuan dari pixel (elemen matriks), nilai nol untuk luminasi hitam dan sedangkan 255 untuk putih, sehingga citra dengan nilai semakin tinggi (dari nol ke 255) mempunyai warna yang semakin terang.

Pada bahasa pemrograman Matlab 6.5, citra dengan format diatas termasuk dalam jenis citra indexed, dan untuk menampilkannya diperlukan peta (map) warna terpisah.

\subsection{Implementasi Perangkat Lu- nak}

Pada Makalah ini, perangkat lunak untuk mensimulasikan reduksi noise citra dengan wavelet ini dibuat dengan bahasa pemrograman Matlab 6.5 yang sudah didukung oleh Graphical User Interface (GUI). Sistem operasi yang digunakan untuk menjalankan perangkat lunak ini adalah Windows 9x/2000/NT. 


\section{Uji Coba Perangkat Lunak}

Proses pengujian dilakukan pada lingkup sistem operasi Windows $X p$ dengan prosesor Pentium $3 \mathrm{CPU} 750 \mathrm{MHz}, 32$ bit graphics. Pengujian dilakukan terhadap tiga jenis citra dengan kompleksitas rendah, tinggi dan sedang. Tiap citra diuji coba dengan tingkat noise yang berbeda, yaitu noise dengan $\sigma=15, \sigma=20$, dan $\sigma=30$. Selanjutnya citra bernoise diproses dengan jenis filter wavelet yang berbeda dan nilai threshold dari masingmasing metode nilai threshold (VisuShrink, BayesShrink dan NormalShrink). Pada Uji coba ini, proses dekomposisi dilakukan sampai dengan empat level dekomposisi. Ketiga jenis citra yang digunakan dalam uji coba adalah citra X-Ray, Lenna dan Mandrill2, ketiganya berekstensi *.mat dan berukuran $512 \times 512$. Berikut ini adalah ketiga citra yang digunakan pada saat uji coba.

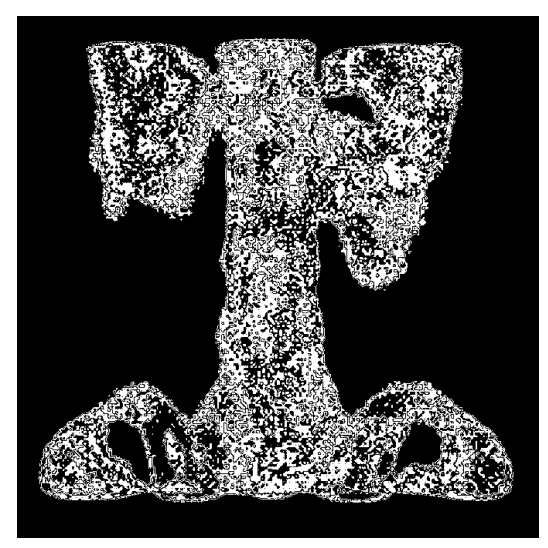

(a) Citra X-Ray.mat, $512 \times 512$

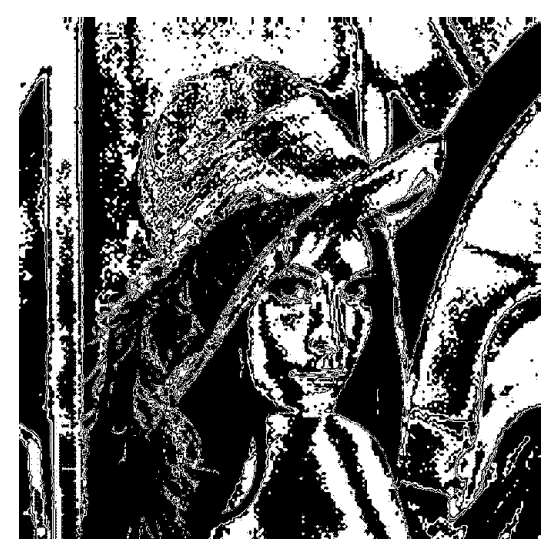

(b) Citra Lenna.mat, $512 \times 512$

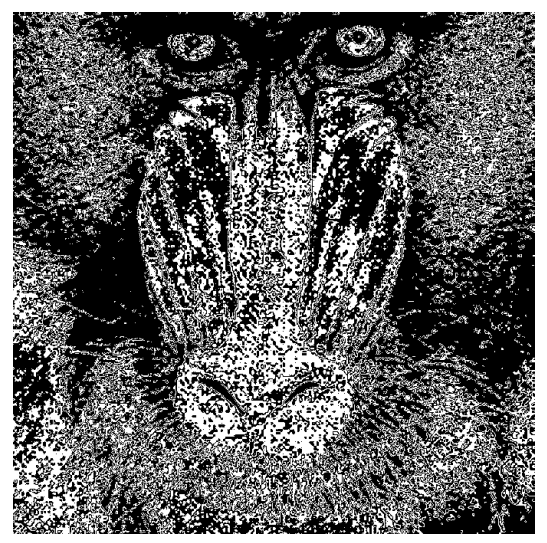

(c) Citra Mandrill2.mat, $512 \times 512$

Gambar 6: Citra-citra untuk uji coba

\subsection{Analisa Hasil Uji}

Coba Analisa hasil uji coba dilakukan berdasarkan tingkat $\sigma$ noise, metode penentuan nilai threshold, dan jenis filter.

\section{Tingkat Noise}

Data hasil uji coba menunjukkan bahwa semakin besar atau tingginya tingkat noise yang diberikan pada citra asli, maka kualitas citra hasil proses reduksi noise yang diperoleh akan semakin jauh dari citra aslinya (citra sebelum diberi noise). Pengaruh tingkat noise terhadap citra hasil, secara obyekif dapat terwakili oleh nilai RMSE. Dimana semakin besar $\sigma$ noise yang diberikan, berakibat semakin bertambahnya nilai RMSE citra hasil reduksi. Grafik pengaruh tingkat $\sigma$ noise terhadap RMSE citra hasil dapat dilihat pada Gambar 7.

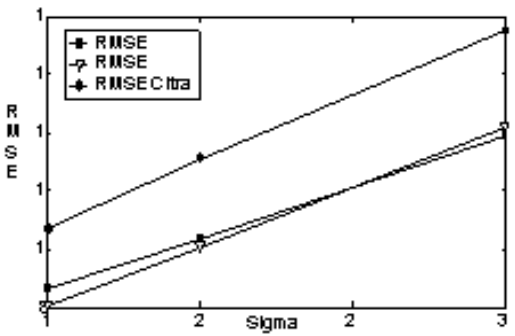

Gambar 7: Grafik pengarus tingkat noise terhadap nilai RMSE

Metode Penentuan Nilai Threshold

Analisa terhadap hasil uji coba reduksi noise pada masing-masing citra masukan, baik secara kualitas visual maupun nilai RMSE adalah sebagai berikut: 
a. Pada Citra Kompleksitas Rendah Untuk noise dengan $\sigma=15$ citra hasil dengan kualitas visual terbaik dan nilai RMSE terendah diberikan oleh metode BayesShrink. Sedangkan untuk noise dengan $\sigma=20$ dan $\sigma=30$ citra hasil dengan kualitas visual terbaik dan RMSE terendah diperoleh dari metode NormalShrink.

b. Pada Citra Kompleksitas Sedang Untuk semua tingkat noise, citra hasil dengan kualitas visual terbaik dan RMSE terendah diperoleh dari metode NormalShrink.

c. Pada Citra Kompleksitas Tinggi Untuk noise dengan $\sigma=15$ dan $\sigma=20$, citra hasil dengan kualitas terbaik secara visual dan RMSE terkecil diperoleh dari penerapan metode BayesShrink. Sedangkan untuk noise dengan $\sigma=30$, citra hasil terbaik diberikan oleh metode NormalShrink.

\section{Jenis Filter}

Analisa terhadap kinerja filter wavelet terhadap citra hasil yang diperoleh dari pengujian perangkat lunak untuk reduksi noise dengan wavelet adalah sebagai berikut:

a. Selain filter Haar, perbedaan nilai RMSE dari citra hasil yang diperoleh dari satu citra noise yang diproses dengan filter yang berlainan tidak terlalu besar. Sehingga perbedaan tersebut tidak terlalu berpengaruh pada kualitas citra hasil secara visual.

b. Filter-filter Symlets dan Coiflets memberikan citra hasil dengan nilai RMSE yang lebih kecil daripada filter-filter Daubechies.

c. Citra hasil reduksi noise dengan nilai RMSE terkecil diperoleh dari citra yang diproses dengan filter Coiflet-5.

\section{Kesimpulan}

Proses reduksi noise pada citra digital dengan penerapan transformasi wavelet diskrit diawali dengan melakukan dekomposisi citra bernoise yang mempunyai resolusi $2^{-j}$ dengan menerapkan transformasi wavelet diskrit 2-D menjadi koefisien-koefisien dengan resolusi $2^{-(j+1)}$. Selanjutnya koefisien-koefisien tersebut direduksi noisenya dengan menerapkan fungsi thresholding. Pada akhir proses, citra direkonstruksi dari koefisien-koefisien yang telah tereduksi noisenya dengan menggunakan invers transformasi wavelet diskrit 2-D, sehingga diperoleh citra yang telah tereduksi noisenya.

Berdasarkan hasil implementasi dan uji coba terhadap perangkat lunak, maka diperoleh hasil antara lain:

a. Filter wavelet yang menghasilkan nilai RMSE terkecil adalah filter Coiflets-5.

b. Metode NormalShrink memberikan hasil optimal pada citra dengan kompleksitas sedang untuk semua tingkat noise, pada citra dengan kompleksitas rendah untuk tingkat noise sedang dan tinggi, dan pada citra dengan kompleksitas tinggi untuk tingkat noise tinggi.

c. Metode BayesShrink memberikan hasil optimal pada citra dengan kompleksitas rendah untuk tingkat noise rendah dan pada citra dengan kompleksitas tinggi untuk tingkat noise relatif rendah dan sedang.

d. Metode NormalShrink memberikan hasil paling optimal dibandingkan dua metode yang lain.

\section{Daftar Pustaka}

[1] Burrus, C.S., Rames A.G. and Haitao G., Introduction to Wavelet and Wavelet Transform: A. Primer, New Jersey Prentice-Hall International Inc., 1998.

[2] Chang, S.G., Yu, B., Vetterli, M., "Adaptive Wavelet Thresholding for Image Denoising and Compression," IEEE Transaction Image Processing, September, 2000.

[3] Chui, C.K, An Introduction to Wavelets, Texas A\&M University College Station, Academic Press Inc., 1992.

[4] Daubechies, I, Ten Lectures on Wavelets, Rutgers University and AT\&T Bell Laboratories, Society for Industrial and Applied Mathematic, Philadelphia, Pennsylvania, 1992.

[5] Donoho, D. L. and Johnstone, I. M., "Ideal Spatial Adaptation via Wavelet Shrinkage," Biometrika, Vol. 81, Agustus 1994.

[6] Donoho, D. L. and Johnstone, I.M., "Adapting to Smoothness via Wavelet Shrinkage," Journal of Statistical Association, Vol. 90, No.432, Desember 1995. 
[7] Kaur, L, Gupta, S and Chauhan, R.C, "Image Denoising using Wavelet Thresholding," IEEE Transaction Image Processing.

[8] Mallat, S.G., "A Theory for Multiresolution Signal Decomposition : The Wavelet Representation," IEEE Transaction on Pattern Analysis and Machine Intellegent, 1989.

[9] Misiti, M., Oppenheim G. and Poggi,
J.M., Wavelet Toolbox User Guide, The MathWork Inc., Maret 2002.

[10] Polikar, R, The Wavelet Tutorial, http://www.public.iastate.edu-/ rpolikar, Durham Computation Center, Iowa State University, 1996.

[11] Stollnitz, E.J., DeRose, T.D., and Salesin D.H., "Wavelet for Computer Graphics: A Primr Part 1," IEEE Computer Graphics And Aplications, Mei, 1995. 